HELMINTHOLOGIA, 58, 1: 28 - 40, 2021

\title{
Minireview
}

\section{Epigenetic markers associated with schistosomiasis}

\author{
R. A. GOMES ASSENÇO ${ }^{1}$, E. ALVES MOTA³, V. F. DE OLIVEIRA ${ }^{3,4}$, W. DE CASTRO BORGES ${ }^{1,2}$, R. GUERRA-SÁ ${ }^{1,3, *}$
}

\begin{abstract}
${ }^{1}$ Programa de Pós-Graduação em Ciências Farmacêuticas (CiPharma), Escola de Farmácia, Universidade Federal de Ouro Preto. Ouro Preto, CEP 35400-000, Minas Gerais, Brazil, " E-mail: rguerra@iceb.ufop.br, ${ }^{2}$ Laboratório de Enzimologia e Proteômica (LEP), Departamento de Ciências Biológicas, Instituto de Ciências Exatas e Biológicas, Universidade Federal de Ouro Preto. Ouro Preto, CEP 35400-000, Minas Gerais, Brazil; ' ${ }^{L}$ aboratório de Bioquímica e Biologia Molecular (LBBM), Departamento de Ciências Biológicas, Instituto de Ciências Exatas e Biológicas, Universidade Federal de Ouro Preto. Ouro Preto, CEP 35400-000, Minas Gerais, Brazil; ${ }^{4}$ Laboratório de Biologia Molecular Aplicada ao Diagnóstico (LABMAD), Departamento de Análises Clínicas e Toxicológicas, Faculdade de Ciências Farmacêuticas, Universidade de São Paulo. São Paulo, CEP 05508-999, São Paulo, Brazil
\end{abstract}

Article info

Received February 18, 2020 Accepted December 1, 2020

\section{Summary}

It is important to consider the use of the epigenome as source of complementary data for genome knowledge, which is suitable for the diagnosis of schistosomiasis. Usually, a laboratory diagnosis of schistosomiasis is performed by means of 1 . Egg detection in the stool or urine by microscopy remains with limited sensitivity; $\mathbf{2}$. Immunological screening, in which positivity persists after treatment, and 3. Molecular appraisals prevail over the disadvantages of the currently used methods. In this sense, molecular methodologies are being developed based on epigenetic biomarkers, aiming to improve the diagnosis of the disease and clinical treatment as early as possible to prevent the occurrence of serious liver damage.

Keywords: Schistosomiasis; DNA methylation; histone modification; miRNAs; epigenetic markers

\section{Introduction}

Schistosomiasis is caused by helminths of the genus Schistosoma, which comprises approximately twenty species, six of which are capable of infecting humans. Schistosoma mansoni, Schistosoma haematobium, and Schistosoma japonicum are the main causative agents of intestinal and urogenital schistosomiasis, which represent the second most prevalent parasitic disease in the world (Weerakoon et al., 2015). Schistosomiasis is one of the 17 neglected tropical diseases (NTDs) prevalent in people and communities living in poverty and social exclusion. This disease reaches around 260 million people worldwide; of these, more than 100 million are children aged 5 to 14 years (Weerakoon et al., 2015). Due to the great social and economic impact of schistosomiasis, the World Health Organization established the year 2025 as a limit for its control or eradication (WHO, 2013). The current problems of schistosomiasis involve factors such as complexity of the Schistosoma sp. life cycle, low drug efficacy, lack of effective vaccines, and limited access to potable water and sanitation in endemic areas. The extent of schistosomiasis is contained to specific areas; its transmission depends on the presence of a susceptible intermediate host, such as snails Biomphalaria ssp., Bulinus ssp., Oncomelania ssp., water conditions, the migration process of people, and anthropogenic activities that cause environmental changes (Colley et al., 2014; Steinmann et al., 2006).

The most effective strategy to control schistosomiasis transmission involves the construction of sewage networks, water treatment, adequate intermediary host elimination strategies, health education, diagnosis, and treatment of infected people (Molehin et al., 2016). Many countries, including Brazil, adopted plans to control schistosomiasis, especially those from less developed regions. However, despite great efforts, the actions employed are still inefficient and schistosomiasis remains a public health issue (Ross et al., 2014).

Efforts have been made to aid in the identification of drug targets and vaccines, the development of diagnoses and chromosome

\footnotetext{
$\bar{*}$ - corresponding author
} 
maps as well as the arrangement and analysis of the genome sequence; for this reason, studies related to the expression of $S$. mansoni genetic material were initiated in the 90 's, with the S. mansoni Genome Project (Loverde et al., 2004; Zerlotini et al., 2010). These studies were carried out by researchers from Universidade Federal de Minas Gerais (UFMG), Centro de pesquisas René Rachou, Fundação Oswaldo Cruz (FIOCRUZ), and with a special contribution of Dr. Craig Venter of the Institute for Genomic Research (IGR), USA. During the period from 1994 to 2000, more than 17,000 expressed sequence tags were identified by means of contributions of Schistosoma Genome Network researchers, supported by the WHO (Franco et al., 1997; Oliveira et al., 2007). This number of potentially expressed tags increased to over 200.000 sequences by 2003 with the publication of the $S$. mansoni transcriptome initiative conducted by a group of researchers in São Paulo state and international collaborators (Verjovski-Almeida et al., 2003). Following these studies, the $S$. mansoni genome was characterized as consisting of seven pairs of autosomal genes and one sexual pair (male ZZ; female ZW) (Zerlotini et al., 2010). In addition, it was established that the genome sequences consist of 380 megabases, covering approximately 12,000 genes that encode (on a provisional basis) different profiles of stage-specific transcriptomes (Anderson et al., 2015; Berriman et al., 2009; Cai et al., 2016).

From studies on the genetics of $S$. mansoni, it was established that the parasites influence host cells by altering both chromatin and DNA. These changes were denominated as epigenetic alterations, which refer to hereditary changes in gene expression that remain stable after some cellular divisions and are not mediated by changes in the DNA sequence (De Oliveira et al., 2017; Roquis et al., 2015). The hereditary marks provide regulatory functions distinct from changes in the base pair sequence of the genome (Stewart-Morgan et al., 2020). Both the genome and the epigenome are influenced by internal and external factors, which interact with each other to determine hereditary effects on the phenotype of individuals, thus leading to differences in genetically identical individuals (Rivera \& Ren, 2013; Shah et al., 2014). The variation of phenotypic characteristics by the action of epigenetic factors, which irreversibly affect gene expression, is an intriguing question for researchers (Weerakoon et al., 2015). The epigenome

\section{B. glabrata}

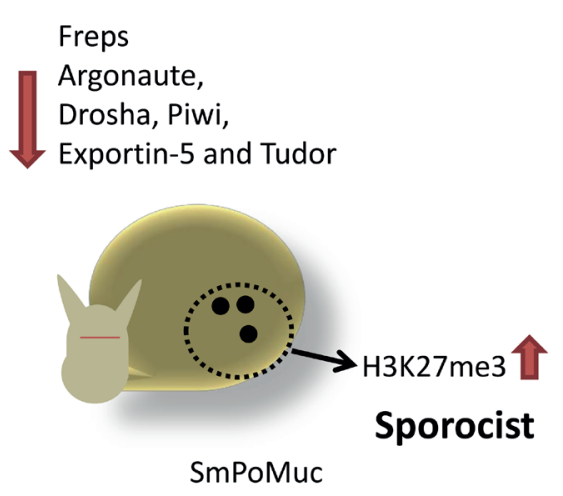

Miracidia

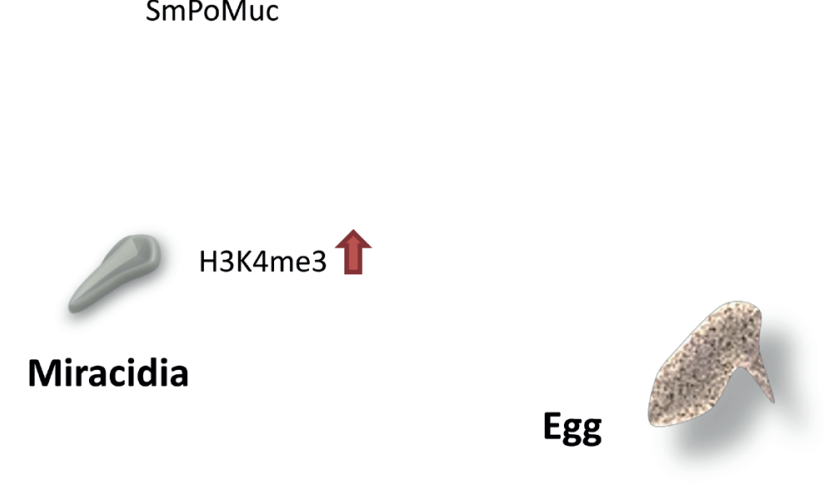

H3K9me3 H3K27me3

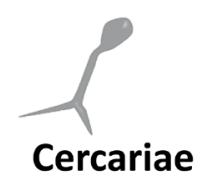

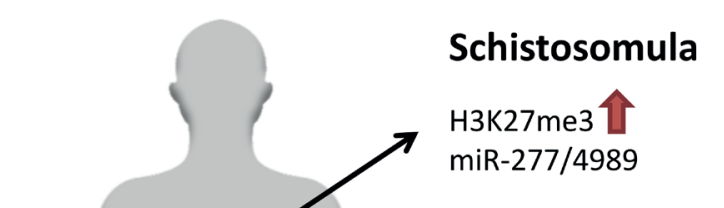

Fig. 1. Epigenetic regulation throughout the S. mansoni cycle: The figure shows some epigenetic marks enriched in the different stages of S. mansoni and some miRNAs involved in parasite-host interaction. Larval stage mucins (SmPoMuc) interact with snail immunity proteins. The intermediate host has downregulation of several miRNA and piRNA biogenesis pathway proteins during miracidium penetration and also during the subsequent stages of development. The most enriched epigenetic marks in cercariae are characteristics of gene silencing. In schistosomes, miRNAs 277 and 4989 may be related to adult worm development. In adults there is an enrichment of epigenetic marks associated with eucromatization. There are miRNAs from the parasite that have already been found in human serum and have been proposed as possible diagnostic biomarkers. 
integrates a set of aspects or phenotypes; being characterized by a dynamic and pliable response to either intra and extracellular stimuli caused by interaction with adjacent cells, exogenous molecules, physiological mechanisms and/or by the environment to which the organism is exposed. The resulted epigenetic changes play an important role in the cell evolution because they are transmitted by more than one generation (Anderson et al., 2012; Shah et al., 2014). Therefore, the epigenome integrates information encoded in the genome with all molecular and chemical signals from cellular, extracellular, and environmental origins (Rivera et al., 2013). Epigenetic mechanisms are essential for the regulation of gene expression and involve a large number of modifications such as DNA methylation in $\mathrm{CpG}$ residues and its demethylation, histone tail modifications, and non-coding RNAs (Berdasco et al., 2018).

From the sequencing of the $S$. mansoni genome, studies on epigenetic mechanisms involved in the development and differentiation of the schistosome have been better understood and are likely to play a crucial role in the transformations occurring at all stages of the Schistosome life cycle; these involve strict control of gene transcription (Cabezas-Cruz et al., 2014). Due to the plasticity of the genome, the life cycle of $S$. mansoni involves a complex differentiation process, to guarantee its survival under different conditions of environmental stress during its free-living phase and at the physiological conditions of a definitive host (Roquis et al., 2016), (Fig. 1).

The spectrum of interactions between the genome and the epigenome of the parasite and the hosts are marked by the presence of epigenetic markers that play important roles in regulatory processes. The aim of this review is therefore to evaluate the main epigenetic factors that can be considered possible epigenetic biomarkers of mansoni schistosomiasis.

\section{Molecular epigenetic markers associated to Schistosomiasis}

A biomarker can be defined as a "marker that reflects or integrates one or more biological activities" that can be detectable and measured (Berdasco et al., 2018). Using biomarkers, it is possible to predict the onset and course of a disease, or to evaluate the patient's response to a specific treatment (Berdasco et al., 2018). The use of biomarkers for diagnosis must consider the characteristics by which a particular disease can be identified and monitored. The assay methods must be widely applicable for most individuals and populations, and they also should present sensitivity and specificity to generate a correct disease diagnosis (Berdasco et al., 2018). In this context, genomic sequences related to the main species of Schistosoma, allied to new technologies, constitute a pathway for the identification of biomarkers and methods of diagnosis, treatment, and control of human schistosomiasis. Methylation epigenetic marks in histones can act as good biomarkers and therapeutic targets. As an example, in S. mansoni larval stages of miracidia, sporocyst and schistosomula were detected predomi- nance of non-constitutive chromatin activated mark, H3K4me3 (trimethyl-histone H3 (Lys4)), in TSS (Transcription start site). Cercariae contained bivalent marks, $\mathrm{H} 3 \mathrm{~K} 4 \mathrm{me} 3$ and $\mathrm{H} 3 \mathrm{~K} 27 \mathrm{me} 3$ also known as trimethyl-histone $\mathrm{H} 3$ (Lys27), that indicates a transitory stage of gene activation and repression in TSS. The same study described an equivalent presence of both three marks in adult worms, nevertheless the repression mark was located upstream and the others at TSS (Roquis et al., 2018). Epigenetic marks as biomarkers are already applied to cancer treatment aiming to trace a personalized therapy based on epialleles profile (Smith et al., 2020). Considering S. mansoni parasites this methodology could be useful in a comparative way among the stages, detecting where are the genes activated in adult and therefore key therapeutic targets. A comparison of epigenetic landscape between susceptible and resistant $S$. mansoni strains could suggest alterations induced by resistance and thus would be possible to outline a treatment to humans infected with resistant strains in the future.

An example of epigenetic writers is the expression of SmCBP1 (Creb-binding protein 1) and SmGCN5 (General control non-repressed 5) that is related to the normal development of eggs and the reproductive system of females. These histone acetyltransferases are recruited by nuclear receptor heterodimer SmRXR1/ SmCBP1 that binds to the Smp14 promoter. SmCBP1 and SmGCN5 leads the histone modification and chromatin decondensation increasing the transcription of that gene. The inhibition of these histone acetyltransferases (HATs) by both RNAi and an enzyme inhibitor in females causes malformation of the eggs, such as abnormal lateral spine, discontinuous or fissured shell and invaginations. In addition, the females have a reduced ovary (Carneiro et al., 2014). This proves that these epigenetic writers could be used as a potential preventive target of schistosomiasis, because eggshell formation is an essential step in egg development; furthermore, viability and egg release are necessary for the transmission and immunopathology of this disease (Carneiro et al., 2009; Carneiro et al., 2014).

The serum of mice and humans infected with $S$. mansoni has elevated quantities of HMGB1 (High mobility group box 1) protein. It is reported that this protein induces several pro-inflammatory cytokines augmenting the hepatic fibrosis process besides inducing the expression of a-SMA (Alfa-smooth muscle actin) in Hepatic Stellate Cells. The inhibition of host's HMGB1 shrinks granuloma areas (Vicentino et al., 2018). Other studies described HMGB1 encoded by S. mansoni and this ortholog, secreted by parasite eggs, also generates inflammatory immune responses. An important fact linked to this protein is related to the presence of lysine sites potentially acetylated by both SmCBP and SmGCN5 (Carneiro et al., 2009). The traffic of human HMGB1 to cytoplasm is mediated by acetylation, but in $S$. mansoni its traffic does not depends on acetyl posttranslational modification. HMGB1 was initially described as a chromosomal protein, important in chromatin structure maintenance and remodeling and also as a transcriptional activator of some specific genes, functioning as an epigenetic reader (De 
Table 1. Main enzymes and reactions involved in epigenetic processes in S. mansoni.

\begin{tabular}{|c|c|c|c|}
\hline Enzyme type & $\begin{array}{l}\text { Reaction } \\
\text { catalyzed }\end{array}$ & $\begin{array}{l}\text { Reaction } \\
\text { example }\end{array}$ & $\begin{array}{l}\text { Access code or } \\
\text { reference }\end{array}$ \\
\hline DNMT2 & DNA methylation & $\begin{array}{l}\text { Cytosine + S-Adenosyl-L-methionine } \\
\text { DNA- methyltransferase Cytosine- } \mathrm{CH}_{3}\end{array}$ & $\begin{array}{l}\text { (Geyer et al., 2011) } \\
\text { Smp_198180 }\end{array}$ \\
\hline HDACs & Histone deacetylation & $\begin{array}{l}\mathrm{H}_{2} \mathrm{O}+N^{6} \text {-acetyl-L-lysyl-[histone] }= \\
\text { acetate }+ \text { L-lysyl-[histone] }\end{array}$ & $\begin{array}{l}\text { SmHDAC1 Smp_005210; } \\
\text { SmHDAC3 Smp_093280; } \\
\text { SmHDAC8 Smp_091990; } \\
\quad \text { (Oger et al., 2008) }\end{array}$ \\
\hline HAT & $\begin{array}{l}\text { Catalyzes acetylation in lysines of } \\
\text { histones and other proteins }\end{array}$ & $\begin{array}{l}\text { Zinc ion binding } \\
\text { Bromodomain } \\
\text { Acetyltransferase activity }\end{array}$ & $\begin{array}{c}\text { AY337317 } \\
\text { Smp_105910 } \\
\text { (Bertin et al., 2006; } \\
\text { Maciel et al., 2004) }\end{array}$ \\
\hline $\begin{array}{l}\text { HMT } \\
\text { PRMT }\end{array}$ & $\begin{array}{l}\text { Protein arginine N-methyltransferase } 1 \\
\text { S-adenosyl-L-methionine } \\
\text { Methyltransferase . Peptidyl-arginine } \\
\text { N-methylation }\end{array}$ & $\begin{array}{l}\text { Catalyze the formation of omega- } \mathrm{N} \\
\text { monomethylarginine (MMA) and } \\
\text { symmetrical dimethylarginine (sDMA). }\end{array}$ & $\begin{array}{c}\text { Smp_070340 } \\
\text { Smp_029240.2 } \\
\text { Smp_025550 } \\
\text { Smp_171150 } \\
\text { Cabezas-Cruz et al., } 2014\end{array}$ \\
\hline PTKs & $\begin{array}{l}\text { Phosphorylation of tyrosine protein } \\
\text { diversity }\end{array}$ & $\begin{array}{l}\text { ATP + a protein-L-tyrosine ADP + a } \\
\text { protein-L-tyrosine phosphate }\end{array}$ & (Avelar et al., 2011) \\
\hline $\begin{array}{l}\text { Ubiquitin- } \\
\text { conjugating } \\
\text { enzymes } \\
\text { (Ub-E2) }\end{array}$ & $\begin{array}{l}\text { Catalyzes the intermediate step of } \\
\text { protein ubiquitination }\end{array}$ & $\begin{array}{l}\text { S-ubiquitinyl-[E1 ubiquitin-activating } \\
\text { enzyme]-L-cysteine + [E2 ubiquitin- } \\
\text { conjugating enzyme]-L-cysteine = } \\
\text { [E1 ubiquitin-activating enzyme]-L- } \\
\text { cysteine + S-ubiquitinyl-[E2 ubiquitin- } \\
\text { conjugating enzyme]-L-cysteine. }\end{array}$ & (Costa et al., 2015) \\
\hline $\begin{array}{l}\text { UCHs, } \\
\text { USPs, OTUs, } \\
\text { MJDs }\end{array}$ & $\begin{array}{l}\text { Involved in ubiquitin processing, in } \\
\text { the recovery of modified ubiquitin } \\
\text { trapped in inactive forms, and in } \\
\text { the recycling of ubiquitin monomers } \\
\text { from polyubiquitinated chains DNA } \\
\text { repair, cell-cycle control, endocytosis, } \\
\text { transcription and protein degradation by } \\
\text { the proteasome }\end{array}$ & $\begin{array}{l}\text { Thiol-dependent hydrolysis of } \\
\text { ester, thioester, amide, peptide and } \\
\text { isopeptide bonds formed by the } \\
\text { C-terminal Glycine of ubiquitin }\end{array}$ & (Pereira et al., 2015) \\
\hline $\begin{array}{l}\text { HMT } \\
\text { PKMT }\end{array}$ & Protein lysine methyltransferase (PKMT) & $\begin{array}{l}\text { L-lysyl-[protein] + S-adenosyl-L- } \\
\text { methionine }=\mathrm{H}^{+}+N^{6} \text {-methyl-L-lysyl- } \\
\text { [protein] + S-adenosyl-L-homocysteine }\end{array}$ & $\begin{array}{c}\text { (Smp } \\
\text { 000700) } \\
\text { (Whatley et al., 2019) }\end{array}$ \\
\hline KDM & Lysine specific demethylase & $\begin{array}{l}\text { Demethylation of 'Lys- } 27 \text { ' of } \mathrm{H} 3 \text { and } \\
\text { appendant methylation of 'Lys-4' } \\
\text { of histone } \mathrm{H} 3 \text {, in agreement with } \\
\text { recruitment of the PRC1 complex and } \\
\text { monoubiquitination of histone } \mathrm{H} 2 \mathrm{~A}\end{array}$ & $\begin{array}{c}\text { (Smp_034000) } \\
\text { (Lobo-Silva et al., 2020) }\end{array}$ \\
\hline
\end{tabular}


Abreu et al., 2016). HMGB1 exhibits promising characteristics of a diagnostic biomarker due to its secretion in sera and of prognosis also due to its different localization profiles during the acute and chronic schistosomiasis (Carneiro et al., 2009; Vicentino et al., 2018).

Among the main non-canonical epigenetic mechanisms microRNAs (miRNAs) have also been implicated in the course of schistosomiasis. Studies have described miRNAs derived from the parasite in the host's serum or derived mainly from the host's liver differentially expressed in the serum during infection by S. mansoni (Meningher et al., 2017). These authors consider that the host's miRNAs are not good biomarkers of schistosomiasis, because in other pathologies that affect the liver such as cirrhosis, hepatitis and cancer. They also present their altered expression profile, in this case they are markers of liver fibrosis or damage (Meningher et al., 2017; Hoy et al., 2014). In this context, detecting parasite derived biomarkers is a more efficient way to achieve specificity in the diagnosis. Epigenetic biomarkers would be advantageous in monosexual infections, in which Kato Katz would be impracticable, and also to detect schistosomiasis in patients infected with resistant strains, since the oviposition of resistant worms is quite reduced in relation to susceptible ones (Abou-El-Naga et al., 2019), in addition to being possible to identify some epigenetic biomarkers already in the schistosomule stage, which remains undetectable in routine tests.

Epigenetic markers are produced through interactions between the parasite and the environment, as well as by interactions with host-specific immune responses. Therefore, to use epigenetic factors as biomarkers, the relationships between parasite and its definitive host must be considered (Mota et al., 2020). In epigenetic processes where the interactions occur by modifying the epigenetic state, there is the participation of enzymes such as: DNA methyltransferases (DNMT), protein arginine methytransferase (PRMT), protein lysine methyltransferase (PKMT), lysine demethylases (KDM), protein lysine acetyltransferase, protein lysine deacetylase (HDAC), kinases, ubiquitin conjugating enzymes (E2), deubiquitinating enzymes (DUBs), and others, presented in Table 1.

Other types of diseases that are also associated to epigenetic pattern alterations, such as miRNA expression, DNA methylation, histone modifications, and others, reinforce the study of epigenetics (Sandoval et al., 2013).

The inflammatory processes observed in mansoni schistosomiasis involves a typical granulomatous lesion formed around the eggs deposited by the parasite. The egg has a squamous epithelium constituting an internal protective membrane called the "von Lichtenberg envelope", which is synthetically active and capable of producing molecules with antigenic properties known as soluble egg antigens (SEAs) (Klaver et al., 2015). When released, the SEAs cross tissues inducing a granulomatous reaction, which is considered late-type hypersensitivity. During the acute phase, the reaction is exacerbated, and the granuloma reaches a volume up to 100 times that of the egg considering rodents as definitive hosts.
In the chronic phase, this granuloma regresses, reaching smaller dimensions (Chuah et al., 2016). During this biological cycle stage, histone acetylation involving HATs is an important mechanism; they enable the expression of egg proteins and the maturation of ovaries in S. mansoni. The inhibition of HATs leads to malformation of the reproductive organs and, consequently, to fragile eggs (Carneiro et al., 2014).

In this context, several findings related to epigenetics involved in biological processes and differentiation stages of $S$. mansoni life cycle are presented in Table 2.

\section{Potential classes of epigenetic biomarkers applied to schisto- somiasis diagnosis: Non-Coding RNAs, methylated DNA, and Histone post-translational modifications}

\section{Non-coding RNAs}

In the last decade, several research groups have performed studies in order to identify miRNAs in parasites of the genus Schistosoma, particularly $S$. japonicum and $S$. mansoni. A few currently known miRNA molecules were characterized based on data obtained by computational approaches associated with deep sequencing techniques (Cai et al., 2013; De Souza et al., 2011; Xue et al., 2008). In the latest version of the genome and proteome of $S$. mansoni, it was established that the content of non-coding DNA sequences is $95.5 \%$, revealing the existence of several non-coding RNAs (ncRNAs) including transfer RNAs (tRNAs), small nucleolar RNAs (snoRNAs), miRNAs and small interfering RNAs (siRNA), and long non-coding RNAs (IncRNAs). The IncRNAs presented functional characteristics such as the presence of an epigenetic tag of transcriptional activation (H3K4me3), evolutionary conservation among other Schistosoma species, and differential expression at all stages of the parasite's life cycle (Maciel et al., 2019; Vasconcelos et al., 2017).

In the miRBase database, more than 3000 miRNAs have been catalogued, being 2661 of humans, 115 of $S$. mansoni, and 61 of $S$. japonicum. These miRNAs were identified and validated through computational resources associated with experimental methodologies such as northern blot, next generation sequencing, real-time PCR, and cloning among others (Kozomara \& Griffiths-Jones, 2014).

In this context, since 2009, researchers in the Laboratory of Biochemistry and Molecular Biology of Universidade Federal de Ouro Preto, Brazil, are working on the characterization of miRNAs of S. mansoni transcriptome and the influence of infection on gene expression. Studies carried out this lab, using an integrated computational approach and systematic analysis of miRNAs, have identified 67 mature miRNAs and 42 precursors in S. mansoni (De Souza et al., 2011; Pereira et al., 2015). 211 new miRNAs had been characterized by cloning small sequences of RNAs obtained from adult S. mansoni (Simões et al., 2011). Reports of 112 miRNAs using deep sequencing in adult worms (Marco et al., 2013), and validation of 20 of the 42 characterized precursors and 2 of 
Table 2. The epigenetic influence in different stages of the S. mansoni life cycle and its involvement in several mechanisms.

\begin{tabular}{|c|c|c|c|c|c|}
\hline $\begin{array}{l}\text { Life } \\
\text { cycle } \\
\text { stage }\end{array}$ & $\begin{array}{l}\text { Developmental } \\
\text { stage }\end{array}$ & $\begin{array}{l}\text { Epigenetic } \\
\text { Findings }\end{array}$ & Gene & Mechanisms & Reference \\
\hline \multirow[t]{3}{*}{$\begin{array}{c}\text { Mammal } \\
\text { host }\end{array}$} & Mature egg & $\begin{array}{c}\text { Epigenetic } \\
\text { readers } \\
\text { characterization }\end{array}$ & $\begin{array}{l}\text { SmMBD2/3 and } \\
\text { SmCBX }\end{array}$ & $\begin{array}{l}\text { Neoblasts } \\
\text { proliferation and } \\
\text { normal eggs } \\
\text { production }\end{array}$ & (Geyer et al., 2018) \\
\hline & Schistosomula & $\begin{array}{l}\text { miRNA enriched } \\
\text { in RNA-seq } \\
\text { analysis: } \\
\text { oesophagus and } \\
\text { tegumental cells } \\
\text { derived. }\end{array}$ & sma-miR-277/4989 & $\begin{array}{l}\text { Downregulation } \\
\text { in paired worms } \\
\text { and upregulation } \\
\text { in virgin worms - } \\
\text { schistosomula to } \\
\text { adult transition }\end{array}$ & Protasio et al., 2017 \\
\hline & Adult worm & $\begin{array}{l}\text { miRNAs parasite- } \\
\text { derived in } \\
\text { definitive host } \\
\text { serum }\end{array}$ & $\begin{array}{l}\text { miR-277, miR-3479-3p and } \\
\text { bantam }\end{array}$ & $\begin{array}{l}\text { Macrophage } \\
\text { proliferation, } \\
\text { TNFa increase } \\
\text { and ovary } \\
\text { development }\end{array}$ & $\begin{array}{l}\text { Hoy et al., 2014, } \\
\text { Zhu et al., } 2016 \\
\text { Liu et al., } 2019\end{array}$ \\
\hline \multirow[t]{2}{*}{ Free life } & Miracidium & $\begin{array}{l}\text { Mucin epigenetic } \\
\text { polymorphisms }\end{array}$ & SmPomucs & $\begin{array}{l}\text { Neutralizing snail } \\
\text { immune system }\end{array}$ & $\begin{array}{l}\text { (Fneich et al., 2016; } \\
\text { Perrin et al., 2013) }\end{array}$ \\
\hline & Cercaria & $\begin{array}{l}\text { miRNA presenting } \\
\text { high rates in a } \\
\text { specific stage }\end{array}$ & miR-71 & $\begin{array}{l}\text { Stage specific } \\
\text { functions }\end{array}$ & Mu et al., 2019 \\
\hline $\begin{array}{l}\text { Snail } \\
\text { Host }\end{array}$ & Sporocyst & IncRNAs RNA-seq & $\begin{array}{l}\text { Unique sets in sporocysts } \\
\text { e.g SmLINC181757 } \\
\text { SmLINC180219 } \\
\text { SmLINC180220 } \\
\text { SmLINC180221 } \\
\text { SmLINC180222 }\end{array}$ & $\begin{array}{l}\text { Asexual } \\
\text { reproduction, } \\
\text { Kinome, } \\
\text { Stage specific } \\
\text { function }\end{array}$ & Kim et al., 2020 \\
\hline
\end{tabular}

the 211 miRNAs isolated in previous studies (Simões et al., 2011). Eleven Schistosoma miRNAs were identified in the serum of S. mansoni-infected mice. The miRNAs Bantam, sma-miR-34733C, sma-miR-277, and sma-miR-3473-3C, of parasite origin, were considered as potential biomarkers for the diagnosis of schistosomiasis (Marco et al., 2013).

The miRNAs are directly associated to the adequate development of ovaries in Schistosoma species. An example of the importance is related to the gametogenesis and egg production that is affected by the suppression of miR-31 and Bantam, conducting to the appearance of vacuoles in ovaries and tissue alterations in parasites (Zhu et al., 2016). Bantam and Sma-miR-2c-3p are the two most expressed circulating miRNAs in the host blood. Thirty days after the start of oviposition, it is already possible to recover de- tectable and expressive amounts of these molecules. As a result, methodologies are being developed to use circulating miRNAs as biomarkers, permitting disease diagnosis and clinical treatment as early as possible to avoid the occurrence of serious liver damage (Meningher et al., 2017).

Among the ncRNAs, miRNAs play important regulatory roles in the differentiation and development of organisms. This has led to new findings of epigenetic mechanisms, although many mechanisms involved in these processes have not yet been fully elucidated (Geisler et al., 2013; Holoch et al., 2015). Due to its important biological role, circulating miRNAs were considered as potential biomarkers for the diagnostic of various diseases because specific miRNAs occur in body fluids such as plasma and serum at significant levels in a stable manner (Sandoval et al., 2013). 
S. mansoni is an extracellular parasite and thus, during its development, displacement, and installation in the definitive host, it releases several molecules that can be detected in the circulatory system of infected individuals (Skelly et al., 2014). For this reason, it is possible to infer that molecules such as circulating RNAs in the serum or plasma of individuals with schistosomiasis could potentially be used as new epigenetic biomarkers (Meningher et al., 2017; Mu et al., 2019).

LncRNAS were detected in S. mansoni, and as they are part of regulatory mechanisms, many approaches have explored the change in the repertoire of these molecules in the transition of stages (Vasconcelos et al., 2017), in different sexes and between susceptible and resistant strains (Oliveira et al., 2018). Recently, changes in epigenetic marks have been associated with IncRNAs at different stages (Maciel et al., 2019) and also a very distinct repertoire of IncRNAs has been detected in sporocysts that the authors associate with regulation of asexual reproduction (Kim et al., 2020). Considering that IncRNAs have little sequence identity between species and that their functionality is more related to conformation than to pairing as in the case of miRNAs they could become good diagnostic biomarkers (Chen et al., 2016).

\section{Methylated DNA}

Epigenetic modifications associated with DNA methylation, involving the incidence of lower (hypomethylation) or higher number of methyl groups (hypermethylation) have been frequently correlated to pathological conditions (Smith et al., 2020). Therefore, the use of DNA methylation as a biomarker represents a great potential strategy for the diagnosis of helminth diseases, such as schistosomiasis.

There is a great deal of information about the enzymes involved in Schistosoma spp. histone alterations such as structural data, inhibitors, possible drugs, and others. However, there is still little knowledge about the mechanisms of DNA methylation in Schistosoma. Two different S. mansoni enzymes - DNA methyltransferase 2 (SmDNMT2) and methyl-CpG binding domain protein (SmMBD) - were demonstrated to be active and essential in DNA methylation as well as very conserved throughout the phylum (Geyer et al., 2013).

There are data on the activity of DNA methyltransferase in the methylation of tRNA and the possible decrease or loss of its methylation properties (Raddatz et al., 2013). However, research shows a possible methylation of the Schistosoma genome in $\mathrm{CpG}$ and $\mathrm{CpA}$, and that the inhibition of this enzyme can maintain eggs in immature stages of development. This makes DNA methylation essential for the maintenance of the Schistosoma sp. life cycle (Geyer et al., 2011; Geyer et al., 2013; Raddatz et al., 2013).

Previous studies have reported DNA methylation used as a biomarker for schistosome infection. In $S$. haematobium for example the promoter of RASSF1A and TIMP3 genes is hypermethylated and can be used as a biomarker of $S$. haematobium infection (Zhong et al., 2013). Disturbance in the global content of 5-mC and in the expression of DNMTs and TETs (Ten eleven translocation) were detected in the liver of infected mice compared to uninfected maybe in the future some specific region or a set of expression profile could be used as schistosomiasis biomarker (Mota et al., 2020).

By means of highly sensitive methods, the occurrence of DNA methylation was emphasized in the $S$. mansoni genome, which was inhibited in 5-azacytidine-treated adult worms, resulting in altered ovarian architecture and production of eggs with abnormal morphology (Geyer et al., 2011). These authors also concluded that if DNA methylation occurs, specific enzymatic mechanisms are involved; however, these mechanisms are not yet known. Although there are specific biochemical processes for DNA methylation, genes that express enzymes like DNTMs and TETs, which are responsible for these mechanisms, were not found in S. mansoni (Geyer et al., 2013). Thus, there is a group of researchers that reports the occurrence of DNA methylation and another that affirms the existence of some controversies regarding the methylation patterns (Fantappié et al., 2001; Raddatz et al., 2013; Geyer et al., 2013; Geyer et al., 2018). This controversy demonstrates the need to obtain conclusive data to confirm or rule out the possibility of adopting $S$. mansoni DNA methylation as a biomarker.

\section{Histone post-translational modifications}

Post-translational modifications (PTMs) are highly dynamically regulated, and involve a set of specific enzymes for different chemical groups and amino acids, which can be: phosphate group, methyl, acetyl, proteins (like ubiquitin and SUMO), carbohydrates, ADP-ribosylation and response to nutrient availability, hormonal stimulation and cellular adaptation mechanisms under different physiological conditions (Wang et al., 2014). Thus, changes in the dynamics of PTMs may have important pathological effects in response to the interaction of Schistosoma with its hosts. Histone modifying enzymes (HMEs), such as HATs, histone methyltransferases (HMTs), and HDACs have been described in S. mansoni. Knowledge about this family of enzymes opens perspectives for additional studies that will lead to a better identification of HMEs, their gene regulation, and the possible development of diagnostic and therapeutic strategies. HDAC enzymes, called Sirtuins (Sirt1, Sirt2, Sirt5, Sirt6, and Sirt7) are encoded by the S. mansoni genome, are NAD+ dependent lysine deacetylases, and are expressed with distinct patterns of expression throughout the life cycle of the parasite. In the same work, the supplementation of sirtuin inhibitors in S. mansoni culture media culminated in schistosomula apoptosis. These inhibitors were able to induce unpairing of worms, alterations on ovary and testis architectures and reduction in oviposition (Lancelot et al., 2013). Other example of targets linked to histone modifications is the HMT enzymes. In vitro assays containing GSK343 (a human EZH2 HMT inhibitor) led to reduction in schistosomula motility and adult worms displayed oviposition and morphology alterations. The authors suggested that the complex of repression Polycomb was affected by the HMT 


\begin{tabular}{|c|c|c|c|c|}
\hline 2000s & $2010 s$ & 2013s & $2016 s$ & 2019s \\
\hline $\begin{array}{l}\text { Lack of DNA } \\
\text { methylation in } \\
\text { S. mansoni } \\
\text { (Fantappié et } \\
\text { al., 2001) }\end{array}$ & $\begin{array}{l}\text { Cytosine } \\
\text { methylation } \\
\text { regulates } \\
\text { oviposition in } \\
\text { the } \\
\text { pathogenic } \\
\text { blood fluke } S \text {. } \\
\text { mansoni } \\
\text { (Geyer et al., } \\
\text { 2013) }\end{array}$ & $\begin{array}{c}\text { Dnmt2- } \\
\text { dependent } \\
\text { methylomes } \\
\text { lack defined } \\
\text { DNA } \\
\text { methylation } \\
\text { patterns } \\
\text { (Raddatz et al., } \\
\text { 2013) }\end{array}$ & $\begin{array}{l}\text { The distinct C- } \\
\text { terminal acidic } \\
\text { domains of } \\
\text { HMGB proteins } \\
\text { are functionally } \\
\text { relevant in S. } \\
\text { mansoni } \\
\text { (De Abreu et } \\
\text { al., 2016) }\end{array}$ & $\begin{array}{l}\text { Methyl-CpG- } \\
\text { binding } \\
\text { proteins in } \\
\text { proliferation } \\
\text { and oviposition } \\
\text { in S. mansoni } \\
\text { (Geyer et al., } \\
\text { 2018) }\end{array}$ \\
\hline \multicolumn{5}{|c|}{ DNA methylation } \\
\hline $\begin{array}{c}\text { S. mansoni } \\
\text { histone } \\
\text { acetyltransferas } \\
\text { e GCN5: } \\
\text { linking histone } \\
\text { acetylation to } \\
\text { gene activation } \\
\text { (Maciel et al., } \\
\text { 2004) }\end{array}$ & $\begin{array}{c}\text { The } \\
\text { extracellular } \\
\text { release of } S \text {. } \\
\text { mansoni } \\
\text { HMGB1 nuclear } \\
\text { protein is } \\
\text { mediated by } \\
\text { acetylation } \\
\text { (Carneiro et al., } \\
\text { 2009) }\end{array}$ & $\begin{array}{c}\text { Sirtuins: } \\
\text { Characterization } \\
\text { and potential as } \\
\text { therapeutic } \\
\text { targets } \\
\text { (Lancelot et al., } \\
\text { 2013) }\end{array}$ & $\begin{array}{l}\text { The epigenome } \\
\text { of } S \text {. mansoni } \\
\text { provides insight } \\
\text { about how } \\
\text { cercariae poise } \\
\text { transcription } \\
\text { until infection } \\
\text { (Roquis et al., } \\
\text { 2015) }\end{array}$ & $\begin{array}{l}\text { Histone } \\
\text { methylation } \\
\text { changes are } \\
\text { required for } \\
\text { life cycle } \\
\text { progression in } \\
\text { the human } \\
\text { parasite } \\
\text { S. mansoni } \\
\text { (Roquis et al., } \\
\text { 2018) }\end{array}$ \\
\hline
\end{tabular}

\section{Histone modification}

\begin{tabular}{|c|c|}
\hline $\begin{array}{c}\text { Identification } \\
\text { and }\end{array}$ & $\begin{array}{c}\text { Genome-wide } \\
\text { identification of } \\
\text { novel } \\
\text { characterization } \\
\text { of novel } \\
\text { microRNAs } \\
\text { from S. }\end{array}$ \\
$\begin{array}{c}\text { microRNAs and } \\
\text { their target } \\
\text { (Xue et al., } \\
\text { 2008) }\end{array}$ & $\begin{array}{c}\text { genes in the } \\
\text { human parasite } \\
\end{array}$ \\
& $\begin{array}{c}\text { S. mansoni } \\
\text { (De Souza et al., } \\
\text { 2011) }\end{array}$ \\
\hline
\end{tabular}

The S. mansoni genome encodes thousands of IncRNAs predicted to be functional at different parasite lifecycle stages (Vasconcelos et al., 2017)
Weighted Gene Co-Expression Analyses Point to Long NonCoding RNA Hub Genes at Different $S$. mansoni LifeCycle Stages (Maciel et al., 2019)

\section{Non-coding RNAs}

Fig. 2. Important advances in DNA methylation, histone modifications, and Non-coding RNAs related to Schistosoma in the last 20 years. 
inhibition when they observed RNA metabolism genes and regulatory molecules gene expression with abnormal levels (Pereira et al., 2018). Therefore, diverse HMEs were considered as potential therapeutic and diagnostic targets for schistosomiasis, because as in the case of sirtuin genes the sequence conservation was restricted to catalytic domains and these were expressed in all parasite life cycle probably due to the relevance of their functions. (Lancelot et al., 2013; Pereira et al., 2018).

Another example of therapeutic epigenetic targets was described in an essay that used $H$. sapiens erasers, writers and readers targets as queries to identify S. mansoni homologues. Inhibitors and miRNAs from these orthologues were supplemented in the cultures of adults and schistosomula causing morphological changes, and the inhibition of a specific HMT resulted in a decrease in the epigenetic mark $\mathrm{H} 3 \mathrm{~K} 36$ me associated with a reduction in motility and in the quantity of eggs produced. These assays open perspectives of treatment during the schistosomula stage (Whatley et al., 2019).

In the case of $S$. mansoni, depending on the susceptibility of the snail, miracidium expresses different configurations of a family of genes related to mucins. Among them, the $S$. mansoni polymorphic mucins (SmPoMucs) are proteins secreted by the apical gland that neutralize proteins of the snail defense system (Perrin et al., 2013). During invasion, epigenetic regulation is best observed through a set of SmPoMucs because there is little change in the nucleotide sequence of the promoter region and the coding region. There are differences in the intensity of methylation and acetylation processes of histone H3K9 in the promoter region of these genes (Fneich et al., 2016). Upon invading the definitive host, the male cercariae respond to chemical stimuli and the females to light stimuli, expressing the proteases necessary for penetration. These enzymes are stage-dependent, and it is probable that their transcription is activated by epigenetic mechanisms of DNA demethylation and/or acetylation of H3K9 (Roquis et al., 2016).

Analysis of $S$. mansoni chromatin indicates that cercariae have low or no level of transcription, because several H3K27me3 repression tags, common in facultative heterochromatin, have been detected. Thus, the transcripts necessary for the survival of the parasite would be synthesized in the previous stages and would be sufficient until the infection of the definitive host, due to the short period of permanence at that stage (Picard et al., 2016).

Adult S. mansoni displays regulatory mechanisms for reproduction, tegument formation, and steroid production, which have not been yet found in other stages of this parasite. There is a marked decrease in H3K27me3, due to the need for synthesis of new transcripts for final host installation (Roquis et al., 2016).

Knowledge of the epigenetic signatures of S. mansoni and an understanding of the intriguing biological role of these molecules is fundamental for the clarification of regulatory processes, the immune response of the mammalian host, and the mechanisms of host and parasite interactions (Cabezas-Cruz et al., 2014; Mota et al., 2020). It is possible to assume that patterns involving DNA methylation, histone modifications, and ncRNA can act as epigenetic biomarkers of schistosomiasis (Berdasco et al., 2018). In this sense, it is necessary to gather collaborative efforts among the scientific community to solve the remaining challenges of the epigenetic biomarkers associated with schistosomiasis, so that new perspectives can be explored.

A timeline of important advances related to DNA methylation, histone modifications, and ncRNA observed for epigenetic biomarkers associated to schistosomiasis in the last 20 years is shown in Figure 2.

\section{Conclusions and future directions}

Although there have been significant advances in the knowledge of genomes, it is still necessary to clarify the essential epigenetic mechanisms involved in the relationship between parasite and host that are responsible for specific diseases such as schistosomiasis; thus, contributing to improve the quality and efficacy of the diagnosis and current treatments (Dawson et al., 2011).

During the S. mansoni life cycle, the parasite needs to adapt to different environmental conditions. With knowledge of the underlying molecular mechanisms it should be possible to mimic, alter, or block specific biochemical pathways in order to hinder or interrupt the transmission of schistosomiasis. In this scenario, the epigenetic contribution to disease is revealing especially relevant. There are already listed potential candidates to be used as biomarkers of schistosomiasis. However, the challenge is to achieve diagnosis based on epigenetic mechanisms as reproducible and accurate as possible. Moreover, the validation of the results will certainly open perspectives for the development of new biomarkers for both schistosomiasis and other helminthic diseases.

\section{Acknowledgements}

The authors are grateful to Sidney Augusto Vieira Filho for valuable suggestions.

\section{Funding}

This work was supported by the Fundação de Amparo à Pesquisa de Minas Gerais (FAPEMIG) (CBB - APQ-02101-11) and the Conselho Nacional de Desenvolvimento Científico e Tecnológico (CNPq) (479317/2012-7).

\section{Conflict of Interest}

The authors declare that they have no conflict of interests.

\section{References}

Abou-El-Naga, I.F., Amer, E.I., Boulos, L.M., El-Faham M.H., Abou SeadA, N.M., Younis, S.S. (2019): Biological and proteomic stud- 
ies of Schistosoma mansoni with decreased sensitivity to praziquantel. Comp Immunol Microbiol Infect Dis., (66): 101341. DOI: 10.1016/j.cimid.2019.101341

Anderson, L., Pierce, R.J., Verjovski-AlmeidA, S. (2012): Schistosoma mansoni histones: From transcription to chromatin regulation; An in-silico analysis. Mol Biochem Parasitol., 183(2): 105 - 114. DOI: 10.1016/j.molbiopara.2012.03.001

Anderson, L., Amaral, M. S., Beckedorff, F., Silva, L. F., DazzaNI, B., Oliveira, K. C., Almeida, G. T., Gomes, M. R., Pires, D. S., Setubal, J. C., Demarco, R., Verjovski-Almeida, S. (2015): Schistosoma mansoni Egg, Adult Male and Female Comparative Gene Expression Analysis and Identification of Novel Genes by RNASeq. PLoS Negl Trop Dis., 9(12): e0004334. DOI: 10.1371/journal. pntd.0004334

Avelar, L.G.A., Nahum, L.A., Andrade, L.F., Oliveira, G. (2011): Functional diversity of the Schistosoma mansoni tyrosine kinases. J Signal Transduct., 2090 - 1739. DOI: 10.1155/2011/603290.

Berdasco, M., Esteller, M. (2018): Clinical epigenetics: seizing opportunities for translation. Nature Reviews Genetics., 20(2): 109 - 127. DOI: 10.1038/s41576-018-0074-2.

Berriman, M., Haas, B.J., Loverde, P.T., Wilson, R.A., Dillon, G.P., Cerqueira, G.C., Mashiyama, S.T., Al-Lazikani, B., Andrade, L.F., Ashton, P.D., Aslett, M.A., Bartholomeu, D.C., Blandin, G., Caffrey, C.R., Coghlan, A., Coulson, R., Day, T.A., Delcher, A., DeMarco, R., DJikeng, A., Eyre, T., Gamble, J.A., Ghedin, E., Gu, Y., Hertz-Fowler, C., Hiral, H., Hiral, Y., Houston, R., Ivens, A., Johnston, D.A., Lacerda, D., Macedo, C.D., McVeigh, P., Ning, Z., Oliveira, G., Overington, J.P., Parkhill, J., Pertea, M., Pierce, R.J., Protasio, A.V., Quall, M.A., Rajandream, M.-A., Rogers, J., Sajid, M., Salzberg, S. L., Stanke, M., Tivey, A. R., White, O., Williams, D.L., Wortman, J., Wu, W., Zamanian, M., Zerlotini, A., Fraser-LigGETT, C.M., BARRELL, B.G., EL-SAYED, N.M. (2009): The genome of the blood fluke Schistosoma mansoni. Nature., 460(7253): 352 358. DOI: 10.1038/nature08160

Bertin, B., Oger, F., Cornette, J., Caby, S., Noël, C., Capron, M., Fantappie, M.R., Rumuanek, F.D., Pierce, R.J. (2006): Schistosoma mansoni CBP/p300 has a conserved domain structure and interacts functionally with the nuclear receptor SmFtz-F1. Mol Biochem Parasitol., 146(2): 180 - 191. DOI: 10.1016/j.molbiopara.2005.12.006

Cabezas-Cruz, A., Lancelot, J., Caby, S., Oliveira, G., Pierce, R.J. (2014): Epigenetic control of gene function in schistosomes: A source of therapeutic targets? Front Genet., 10(5): 317. DOI: 10.3389/fgene.2014.00317

Cal, P., Piao, X., Hao, L., Liu, S., Hou, N., Wang, H., Chen, Q. (2013): A deep analysis of the small non-coding RNA population in Schistosoma japonicum eggs. PLoS One., 8(5): e64003. DOI: 10.1371/journal.pone. 0064003

Cal, P., Liu, S., Piao, X., Hou, N., Gobert, G.N., McManus, D.P., Chen, Q. (2016): Comprehensive Transcriptome Analysis of Sex-Biased Expressed Genes Reveals Discrete Biological and Physiological Features of Male and Female Schistosoma japoni- cum. PLoS Negl Trop Dis., 10(4): e0004684. DOI: 10.1371/JOURNAL.PNTD.0004684

Carneiro, V.C., De Moraes Maciel, R., De Abreu Da Silva, I.C., Da Costa, R.F.M., Paiva, C.N., Bozza, M.T., Fantapplé, M.R. (2009): The extracellular release of Schistosoma mansoni HMGB1 nuclear protein is mediated by acetylation. Biochem Biophys Res Commun., 390(4): 1245 - 1249. DOI: 10.1016/j.bbrc.2009.10.129 Carneiro, V.C., De Abreu Da Silva, I.C., Torres, E.J.L., Caby, S., Lancelot, J., Vanderstraete, M., Furdas, S.D., Jung, M., Pierce, R.J., FANTAPPIÉ, M.R. (2014): Epigenetic Changes Modulate Schistosome Egg Formation and Are a Novel Target for Reducing Transmission of Schistosomiasis. PLoS Pathog., 10(5): e1004116. DOI: 10.1371/journal.ppat.1004116

CHEN, L.-L. (2016): Linking Long Noncoding RNA Localization and Function. Trends in Biochemical Sciences., 41(9): 761 - 772 DOI: 10.1016/j.tibs.2016.07.003

Chuah, C., Jones, M.K., McManus, D.P., Nawaratna, S.K., Burke, M.L., Owen, H.C., RAmm, G.A., Gobert, G.N. (2016): Characterising granuloma regression and liver recovery in a murine model of schistosomiasis japonica. Int J Parasitol., 46(4): 239 - 252. DOI: 10.1016/j.ijpara.2015.12.004

Colley, D.G., Bustinduy, A.L., SeCor, W.E., King, C.H. (2014): Human schistosomiasis. In: The Lancet., 383(9936): 2253 - 2264. DOI: 10.1016/S0140-6736(13)61949-2.

Costa, M.P., Oliveira, V.F., Pereira, R.V., de Abreu, F.C., JannottI-PASSOS, L.K., Borges, W.C., Guerra-SÁ, R. (2015): In silico analysis and developmental expression of ubiquitin-conjugating enzymes in Schistosoma mansoni. Parasitol Res., (114): 1769 1777. DOI: 10.1007/s00436-015-4362-x

Dawson, M.A., Prinjha, R.K., Dittmann, A., Glotopoulos, G., Bantscheff, M., Chan, W.I., Robson, S.C., Chung, C.W., Hopf, C., Savitski, M.M., Huthmacher, C., Gudgin, E., Lugo, D., Beinke, S., Chapman, T.D., Roberts, E.J., Soden, P.E., Auger, K.R., Mirguet, O., Doehner, K., Delwel, R., Burnett, A.K., Jeffrey, P., Drewes, G., LeE, K., Huntly, B.J., Kouzarides, T. (2011): Inhibition of BET recruitment to chromatin as an effective treatment for MLL-fusion leukaemia. Nature., 478(7370): 529 - 533. DOI: 10.1038/ nature10509

De Abreu Da Silva, I.C., Carneiro, V.C., Vicentino, A.R.R., Aguilera, E.A., Mohana-Borges, R., Thiengo, S., Fernandez, M.A., Fantapplé, M.R. (2016): The distinct C-terminal acidic domains of HMGB proteins are functionally relevant in Schistosoma mansoni. Int J Parasitol., 46(4): 253 - 262. DOI: 10.1016/j.jpara.2015.12.007

De Oliveira, F.L., Carneiro, K., Brito, J.M., Cabanel, M., Pereira, J.X., PaIVA, L.A., Syn, W., Henderson, N.C., El-Cheikh, M.C. (2017): Galectin-3, histone deacetylases, and Hedgehog signaling: Possible convergent targets in schistosomiasis-induced liver fibrosis. PLoS Negl Trop Dis.,11(2): e0005137. DOI: 10.1371/journal. pntd.0005137

De Souza Gomes, M., Muniyappa, M.K., Carvalho, S.G., Guerra-SÁ, R., SPILlane, C. (2011): Genome-wide identification of novel microRNAs and their target genes in the human parasite Schis- 
tosoma mansoni. Genomics., 98(2): 96 - 111. DOI: 10.1016/j. ygeno.2011.05.007

Fantapplé, M.R., Gimba, E.R., RumJanek, F.D. (2001): Lack of DNA methylation in Schistosoma mansoni. Exp Parasitol., 98(3): 162 166. DOI: $10.1006 /$ expr.2001.4630

Fneich, S., Théron, A., Cosseau, C., Rognon, A., Aliaga, B., Buard, J., Duval, D., Arancibia, N., Boissier, J., Roquis, D., Mitta, G., Grun$\mathrm{AU}, \mathrm{C}$. (2016): Epigenetic origin of adaptive phenotypic variants in the human blood fluke Schistosoma mansoni. Epigenetics and Chromatin., 9(27). DOI: 10.1186/s13072-016-0076-2

Franco, G.R., Rabelo, É.M.L., Azevedo, V., Pena, H.B., Ortega, J.M, Santos, T.M., Meira, W.S., Rodrigues, N.A., Dias, C.M., Harrop, R., Wilson, A., Saber, M., Abdel-Hamid, H., Faria, M.S., Margutti, M.E., PARRA, J.C., PENA, S.D. (1997): Evaluation of cDNA libraries from different developmental stages of Schistosoma mansoni for production of expressed sequence tags (ESTs). DNA Res., 4(3): 231 - 240. DOI: 10.1093/dnares/4.3.231

GeIsLer, S., Coller, J. (2013): RNA in unexpected places: Long non-coding RNA functions in diverse cellular contexts. Nat Rev Mol Cell Biol., 14(11): 699 - 712. DOI: 10.1038/nrm3679

Geyer, K.K., Rodriguez López, C.M., Chalmers, I.W., Munshi, S.E., Truscott, M., Heald, J., Wilkinson, M.J., Hoffmann, K.F. (2011): Cytosine methylation regulates oviposition in the pathogenic blood fluke Schistosoma mansoni. Nat Commun., 2(424). DOI: 10.1038/ ncomms 1433

Geyer, K.K., Chalmers, I.W., Mackintosh, N., Hirst, J.E., Geoghegan, R., Badets, M., Brophy, P.M, Brehm, K., Hoffmann, K.F. (2013): Cytosine methylation is a conserved epigenetic feature found throughout the phylum Platyhelminthes. BMC Genomics., (14):462. DOI: 10.1186/1471-2164-14-462

Geyer, K.K., Munshi, S.E., Whiteland, H.L., Fernandez-Fuentes, N., Phillips, D.W., Hoffmann, K.F. (2018): Methyl-CpG-binding (SmMBD2/3) and chromobox (SmCBX) proteins are required for neoblast proliferation and oviposition in the parasitic blood fluke Schistosoma mansoni. PLoS Pathog., 14(6): e1007107. DOI: 10.1371/journal.ppat.1007107

Han, Z-G., Brindley, P.J., Wang, S-Y., Chen, Z. (2009): Schistosoma Genomics: New Perspectives on Schistosome Biology and Host-Parasite Interaction. Annu Rev Genomics Hum Genet., (10): 211 - 240. DOI: 10.1146/annurev-genom-082908-150036

Holoch, D., Moazed, D. (2015): RNA-mediated epigenetic regulation of gene expression. Nat Rev Genet., 16(2): 71 - 84. DOI: 10.1038/NRG3863

Hoy, A.M., Lundie, R.J., Ivens, A., Quintana, J.F., Nausch, N., FoRster, T., Jones, F., Kabatereine, N.B., Dunne, D.W., Mutapi, F., MacDonald, A.S., Buck, A.H. (2014): Parasite-derived microRNAs in host serum as novel biomarkers of helminth infection. PLoS Negl Trop Dis., 8(2): e2701. DOI: 10.1371/journal.pntd.0002701

KIM, C.H., KHALL, A.M., Jolly, E.R. (2020): LncRNAs in molluscan and mammalian stages of parasitic schistosomes are developmentally regulated and coordinately expressed with protein-coding genes. RNA Biology., 1555 - 8584. DOI:
10.1080/15476286.2020.1729594

KLAVER, E.J., KUIJK, L.M., LindHORSt, T.K., Cummings, R.D., VAN Die, I. (2015): Schistosoma mansoni soluble egg antigens induce expression of the negative regulators SOCS1 and SHP1 in human dendritic cells via interaction with the mannose receptor. PLOS One., 10(4): e0124089. DOI: 10.1371/journal.pone.0124089

Kozomara, A., GRIFFITHS-Jones, S. (2014): miRBase: annotating high confidence microRNAs using deep sequencing data. Nucleic Acids Res., 42(Database issue): D68 - 73. DOI: 10.1093/nar/ gkt1181

Lancelot, J., Caby, S., Dubols-Abdesselem, F., Vanderstraete, M., Trolet, J., Oliveira, G., Bracher, F., Jung, M., Pierce, R.J. (2013): Schistosoma mansoni Sirtuins: Characterization and potential as chemotherapeutic targets. PLoS Negl Trop Dis., 7(9): e2428. DOI: 10.1371/journal.pntd.0002428

Liu, J., Zhu, L., Wang, J., QuU, L., Chen, Y., Davis, R.E., Cheng, G. (2019): Schistosoma japonicum extracellular vesicle miRNA cargo regulates host macrophage functions facilitating parasitism. PLoS Pathog., 15(6): e1007817. DOI: 10.1371/journal.ppat.1007817 Lobo-Silva, J., Cabral, F.J., Amaral, M.S., Miyasato, P.A., de Freitas, R.P., Pereira, A.S.A., Khouri, M.I., Barbosa, M.M.F., Ramos, P.I.P., Leite, L.C.C., Asojo, O.A., Nakano, E., Verjovski-Almeida, S., FARIAS, L.P. (2020): The antischistosomal potential of GSK-J4, an H3K27 demethylase inhibitor: insights from molecular modeling, transcriptomics and in vitro assays. Parasites Vectors., 13(140). DOI: 10.1186/s13071-020-4000-z

Loverde, P.T., Hiral, H., Merrick, J.M., Lee, N.H., El-Sayed, N. (2004): Schistosoma mansoni genome project: An update. Parasitol Int., 53(2): 183 - 192. DOI: 10.1016/j.parint.2004.01.009

Maciel, R.D.M., Dutra, D.L.dS., Rumuanek, F.D., Juliano, L., JuLIANO, M.A., FANTAPPIÉ, M.R. (2004): Schistosoma mansoni histone acetyltransferase GCN5: Linking histone acetylation to gene activation. Mol Biochem Parasitol., 133(1): 131 - 135. DOI: 10.1016/j. molbiopara.2003.09.005

Maciel, L.F., Morales-Vicente, D.A., Silveira, G.O., Ribeiro, R.O., Olberg, G.G.O., Pires, D.S., Amaral, M.S., Verjovski-AlmelDA, S. (2019): Weighted gene co-expression analyses point to long non-coding RNA hub genes at different Schistosoma mansoni life-cycle stages. Front Genet., (10): 823. DOI: 10.3389/ FGENE.2019.00823

Marco, A., Kozomara, A., Hul, J.H.L., Emery, A.M., Rollinson, D., GRIFFITHS-Jones, S., Ronshaugen, M. (2013): Sex-biased expression of microRNAs in Schistosoma mansoni. PLoS Negl Trop Dis., 7(9): e2402. DOI: 10.1371/journal.pntd.0002402

Meningher, T., Lerman, G., Regev-Rudzki, N., Gold, D., Ben-Dov, I.Z., SIDI, Y., AvNI, D., SchwarTZ, E. (2017): Schistosomal microRNAs isolated from extracellular vesicles in sera of infected patients: a new tool for diagnosis and follow-up of human schistosomiasis. $J$ Infect Dis., 215(3): 378 - 386. DOI: 10.1093/infdis/jiw539

Molehin, A.J., Rojo, J.U., Siddiqui, S.Z., Gray, S.A., CartER, D., SIDDIQUI, A.A. (2016): Development of a schistosomiasis vaccine. Expert Rev Vaccines., 15(5): 619 - 627. DOl: 


\section{$10.1586 / 14760584.2016 .1131127$}

Mota, E.A., Patrocinio, A.B.D., Rodrigues, V., Da Silva, J.S., PerelRA, V.C., GuerRA-SA, R. (2020): Epigenetic and parasitological parameters are modulated in $\mathrm{EBi}^{-\%}$ mice infected with Schistosoma mansoni. PLoS Negl Trop Dis., 14(2): e0008080. DOI: 10.1371/ journal.pntd. 0008080

Mu, Y., Cal, P., Olveda, R.M., Ross, A.G., Olveda, D.U., Mcmanus, D.P. (2019): Parasite-derived circulating microRNAs as biomarkers for the detection of human Schistosoma japonicum infection. Parasitology., 1 - 8. DOI: 10.1017/S0031182019001690

Oger, F., Dubols, F., Caby, S., Noël, C., Cornette, J., Bertin, B., Capron, M., Pierce, R.J. (2008): The class I histone deacetylases of the platyhelminth parasite Schistosoma mansoni. Biochem Biophys Res Commun., 377(4): 1079 - 1084. DOI: 10.1016/j. bbrc.2008.10.090

OliveIRA, G. (2007): The Schistosoma mansoni transcriptome: An update. Experimental Parasitology., 117(3): 229 - 235. DOI: 10.1016/j.exppara.2007.06.001

Oliveira, V.F., Moares, L.A.G., Mota, E.A., Jannotti-Passos, L.K., Coelho, P.M.Z., Mattos, A.C.A., Couto, F.F.B., Caffrey, B.E., MarSICO, A., Guerra-SA, R. (2018): Identification of 170 New Long Noncoding RNAs in Schistosoma mansoni. Biomed Res Int., (2018): 1264697. DOI: $10.1155 / 2018 / 1264697$

Pereira, R.V., De Souza Gomes, M., Costa, M.P., Jannotti Passos, L.K., De Castro Borges, W., Guerra-SA, R. (2015): MJD and OTU deubiquitinating enzymes in Schistosoma mansoni. Parasitol Res., 114(8): 2835 - 2843. DOI: 10.1007/s00436-015-4484-1

Pereira, A.S.A, Amaral, M.S., Vasconcelos, E.J.R., Pires, D.S., Asif, H., da Silva, L.F., Morales-Vicente, D.A., Carneiro, V.C., ANgel, C.B., Palmisano, G., Fantappie, M.R., Pierce, R.J., Setubal, J.C., VerJovski-AlmeIDA, S. (2018): Inhibition of histone methyltransferase EZH2 in Schistosoma mansoni in vitro by GSK343 reduces egg laying and decreases the expression of genes implicated in DNA replication and noncoding RNA metabolism. PLoS Negl Trop Dis., 12(10): e0006873. DOI: 10.1371/journal.pntd.0006873 Perrin, C., Lepesant, J.M.J., Roger, E., Duval, D., Fneich, S., Thuillier, V., Alliene, J.F., Mitta, G., Grunau, C., Cosseau, C. (2013): Schistosoma mansoni Mucin Gene (SmPoMuc) Expression: Epigenetic control to shape adaptation to a new host. PLoS Pathog., 9(8): e1003571. DOI: 10.1371/journal.ppat.1003571

Picard, M.A., Boissier, J., Roquis, D., Grunau, C., Allienne, J.F., Duval, D., Toulza, E., Arancibia, N., Caffrey, C.R., Long, T., Nidelet, S., Rohmer, M., Cosseau, C. (2016): Sex-Biased Transcriptome of Schistosoma mansoni: Host-Parasite Interaction, Genetic Determinants and Epigenetic Regulators Are Associated with Sexual Differentiation. PLoS Negl Trop Dis., 10(9): e0004930. DOI: 10.1371/journal.pntd.0004930

Protasio, A.V., Van Dongen, S., Collins, J., Quintals, L., RibeIro, D.M., Sessler, F., Hunt, M., Rinaldi, G., Collins, J.J., EnRIGht, A.J., BERRIMAN, M. (2017): MiR-277/4989 regulate transcriptional landscape during juvenile to adult transition in the parasitic helminth Schistosoma mansoni. PLoS Negl Trop Dis., 11(5): e0005559.
DOI: 10.1371/journal.pntd.0005559

Raddatz, G., Guzzardo, P.M., Olova, N., Fantappié, M.R., Rampp, M., Schaefer, M., ReIK, W., Hannon, G.J., Lyko, F. (2013): Dnmt2-dependent methylomes lack defined DNA methylation patterns. Proc Natl Acad Sci USA., 110(21): 8627 - 8631. DOI: 10.1073/ PNAS. 1306723110

Rivera, C.M., Ren, B. (2013): Mapping human epigenomes. Cell., 155(1): 39 - 55. DOI: 10.1016/j.cell.2013.09.01

Roquis, D., Lepesant, J.M.J., Picard, M.A.L., Freitag, M., Parrinello, H., Groth, M., Emans, R., Cosseau, C., Grunau, C. (2015): The epigenome of Schistosoma mansoni provides insight about how cercariae poise transcription until infection. PLoS Negl Trop Dis., 9(8): e0003853. DOI: 10.1371/journal.pntd.0003853

Roquis, D., Rognon, A., Chaparro, C., Boissier, J., Arancibia, N., Cosseau, C., Parrinello, H., Grunau, C. (2016): Frequency and mitotic heritability of epimutations in Schistosoma mansoni. Mol Ecol., 25(8): 1741 - 1758. DOI: 10.1111/mec.13555

Roquis, D., Taudt, A., Geyer, K.K., Padalino, G., Hoffmann, K.F., Holroyd, N., Berriman, M., Aliaga, B., Chaparro, C., Grunau, C., Augusto, R.C. (2018): Histone methylation changes are required for life cycle progression in the human parasite Schistosoma mansoni. PLoS Pathog., 14(5): e1007066. DOI: 10.1371/journal. ppat.1007066

Ross, A., Inobaya, M., Olveda, R., Chau, T., Olveda, D. (2014): Prevention and control of schistosomiasis: a current perspective. Res Rep Trop Med., (5): 65 - 75. DOI: 10.2147/RRTM.S44274

Sandoval, J., Peiró-Chova, L., Pallardó, F.V., Garcia-Giménez, J.L. (2013): Epigenetic biomarkers in laboratory diagnostics: Emerging approaches and opportunities. Expert Rev Mol Diagn., 13(5): 457 - 471. DOI: 10.1586/erm.13.37

Shah, S., Mcrae, A.F., Marioni, R.E., Harris, S.E., Gibson, J., Henders, A.K., Redmond, P., Cox, S.R., Pattie, A., Corley, J., Murphy, L., Martin, N.G., Montgomery, G.W., StarR, J.M., Wray, N.R., DeARY, I.J., VISSCHER, P.M. (2014): Genetic and environmental exposures constrain epigenetic drift over the human life course. Genome Res., 24(11): 1725 - 1733. DOI: 10.1101/gr.176933.114 Simöes, M.C., Lee, J., Duikeng, A., Cerqueira, G.C., Zerlotinl, A., Da Silva-Pereira, R.A., Dalby, A.R., LoVerde, P., El-Sayed, N.M., OLIVEIRA, G. (2011): Identification of Schistosoma mansoni microRNAs. BMC Genomics., (12):47. DOI: 10.1186/1471-2164-12-47

Skelly, P.J., Da'dara, A.A., LI, X.H., Castro-Borges, W., Wilson, R.A. (2014): Schistosome Feeding and Regurgitation. PLoS Pathog., 10(8): e1004246. DOI: 10.1371/journal.ppat. 1004246

Smith, J., Sen, S., Weeks, R.J., Eccles, M.R., Chatterjee, A. (2020): Promoter DNA Hypermethylation and Paradoxical Gene Activation. Trends in Cancer., 6(5): 392 - 406. DOI: 10.1016/j.trecan.2020.02.007

Steinmann, P., Keiser, J., Bos, R., Tanner, M., Utzinger, J. (2006): Schistosomiasis and water resources development: systematic review, meta-analysis, and estimates of people at risk. Lancet Infectious Diseases., 6(7): 411 - 425. DOI: 10.1016/S14733099(06)70521-7 
Stewart-Morgan, K.R., Petryk, N., Groth, A. (2020): Chromatin replication and epigenetic cell memory. Nat Cell Biol., (22): 361 371. DOI: 10.1038/s41556-020-0487-y

Vasconcelos, E.J.R., Dasilva, L.F., Pires, D.S., Lavezzo, G.M., Pereira, A.S.A., Amaral, M.S., Verjovski-Almeida, S. (2017): The Schistosoma mansoni genome encodes thousands of long non-coding RNAs predicted to be functional at different parasite life-cycle stages. Sci Rep., 7(10508). DOI: 10.1038/s41598-01710853-6

Verjovski-Almeida, S., Demarco, R., Martins, E., Guimarães, P.E.M., Ojopi, E.P.B., Paquola, A.C.M., Piazza, J.P., Nishiyama JR, M.Y., Kitauma, J.P., Adamson, R.E., Ashton, P.D., Bonaldo, M.F., Coulson, P.S., Dillon, G.P., Farias, L.P., Gregorio, S.P., Ho, P.L., Leite, R.A., Malaquias, L.C.C., Marques, R.C.P., Miyasato, P.A., Nascimento, A.L.T.O., Ohlweiler, F.P., Reis, E.M., Ribeiro, M.A., Guerra-Sá, R., Stukart, G.C., Soares, M.B., Gargioni, C., Kawano, T., Rodrigues, V., Madeira, A.M.B.N., Wilson, R.A., Menck, C.F.M., Setubal, J.C., Leite, L.C.C., Dias-Neto, E. (2003): Transcriptome analysis of the acoelomate human parasite Schistosoma mansoni. Nat Genet., (35): 148 - 157. DOI: 10.1038/ng1237

Vicentino, A.R.R., Carneiro, V.C., Allonso, D., Guilherme, R.F., Benjamim, C.F., Dos Santos, H.A.M., Xavier, F., Pyrrho, A.D.S., Gomes, J.A.S., FonseCA, M.C., de Oliveira, R.C., Pereira, T.A., LADISLAU, L., LAMBERTUCCI, J.R., FANTAPPIÉ, M.R. (2018): Emerging Role of HMGB1 in the Pathogenesis of Schistosomiasis Liver Fibrosis. Front Immunol., (9):1979. DOl:10.3389/fimmu.2018.01979

Wang, Y., Peterson, S., LoRING, J. (2014): Protein post-translational modifications and regulation of pluripotency in human stem cells. Cell Res., (24): 143 - 160. DOI: 10.1038/CR.2013.151

Weerakoon, K.G.A.D., Gobert, G.N., Cal, P., McManus, D.P. (2015):
Advances in the diagnosis of human schistosomiasis. Clin Microbiol Rev., 28(4): 939 - 967. DOI: 10.1128/CMR.00137-14 Whatley, K.C.L., Padalino, G., Whiteland, H., Geyer, K.K., Hulme, B.J., Chalmers, I.W., Forde-Thomas, J., Ferla, S., Brancale, A., Hoffmann, K.F. (2019): The repositioning of epigenetic probes/ inhibitors identifies new anti-schistosomal lead compounds and chemotherapeutic targets. PLoS Negl Trop Dis., 13(11): e0007693. DOI: 10.1371/journal.pntd.0007693

World Health Organization (2013): Sustaining the drive to overcome the global impact of neglected tropical diseases: second WHO report on neglected tropical diseases. Geneva

Xue, X., Sun, J., Zhang, Q., Wang, Z., Huang, Y., Pan, W. (2008): Identification and characterization of novel microRNAs from Schistosoma japonicum. PLoS One., 3(12): e4034. DOI: 10.1371/journal.pone.0004034

Zerlotini, A., Oliveira, G. (2010): The contributions of the genome project to the study of schistosomiasis. Mem Inst Oswaldo Cruz., 105(4): 367 - 369. DOI: 10.1590/S0074-02762010000400003

Zhong, X., Isharwal, S., Naples, J.M., ShifF, C., Veltri, R.W., Shao, C., Bosompem, K.M., Sidransky, D., Hoque, M.O. (2013): Hypermethylation of genes detected in urine from Ghanaian adults with bladder pathology associated with Schistosoma haematobium infection. PLoS One., 8(3): e59089. DOI: 10.1371/journal. pone.0059089

Zhu, L., Zhao, J., Wang, J., Hu, C., Peng, J., Luo, R., Zhou, C., Liu, J., Lin, J., Jin, Y., Davis, R.E., Cheng, G. (2016): MicroRNAs Are Involved in the Regulation of Ovary Development in the Pathogenic Blood Fluke Schistosoma japonicum. PLOS Pathogens., 12(2): e1005423. DOI: 10.1371/journal.ppat.1005423 